\title{
Curcumin inhibits cell proliferation and migration in NSCLC through a synergistic effect on the TLR4/MyD88 and EGFR pathways
}

\author{
LANFENG ZHANG ${ }^{1-3^{*}}$, XINGYU TAO ${ }^{1 *}$, QIAOFEN FU ${ }^{2 *}$, CHUNLEI GE $^{2}$, RUILEI LI ${ }^{2}$, \\ ZHEN LI ${ }^{2}$, YE ZHU ${ }^{4}$, HUI TIAN ${ }^{2}$, QIAOLIN LI ${ }^{2}$, MIN LIU $^{2}$, HONGYAN HU ${ }^{5}$, BAOZHEN ZENG ${ }^{2}$, \\ ZHUYIN LIN ${ }^{6}$, CHUNYAN LI ${ }^{2}$, RONGCHENG LUO ${ }^{1}$ and XIN SONG ${ }^{1,2}$
}

\begin{abstract}
${ }^{1}$ Cancer Center, Integrated Hospital of Traditional Chinese Medicine, Southern Medical University, Guangzhou, Guangdong 510315; ${ }^{2}$ Department of Cancer Biotherapy Center, The Third Affiliated Hospital of Kunming Medical University (Tumor Hospital of Yunnan Province), Kunming, Yunnan 510118; ${ }^{3}$ General Practice, The Affiliated Hospital of Hebei University, Baoding, Hebei 071000; ${ }^{4}$ Department of Medical Oncology, The Central Hospital of Hengyang, Hengyang, Hunan 421000; ${ }^{5}$ Department of Pathology, The Third Affiliated Hospital of Kunming Medical University (Tumor Hospital of Yunnan Province), Kunming, Yunnan 510118; ${ }^{6}$ Central Laboratory of Yan'an Hospital Affiliated to Kunming Medical University, Kunming, Yunnan 650051, P.R. China
\end{abstract}

Received September 28, 2018; Accepted May 31, 2019

DOI: 10.3892/or.2019.7278

\begin{abstract}
Despite the increasing number of available therapeutic methods, the prognosis of non-small cell lung cancer (NSCLC) remains poor. Furthermore, side effects are an important limiting factor in the treatment of NSCLC. Therefore, developing an efficacious, safe, affordable and easily accessible chemotherapeutic agent is necessary for NSCLC treatment. As a natural chemical produced by Zingiberaceae plants, curcumin exerts distinct antitumor effects on several tumor types. In the present study, curcumin was observed to inhibit not only cell proliferation and cell cycle transition, but also cell migration in NSCLC, as determined by a series of experiments (such as MTS assay, colony formation assay, flow cytometric analysis, Transwell migration assay and western blotting). Mechanistically, curcumin induced $\mathrm{G}_{2} / \mathrm{M}$ phase arrest by controlling cell cycle- and epithelial-mesenchymal transition (EMT)-related checkpoints. Furthermore, curcumin significantly inhibited the expression of Toll-like receptor 4
\end{abstract}

Correspondence to: Professor Rongcheng Luo or Professor Xin Song, Cancer Center, Integrated Hospital of Traditional Chinese Medicine, Southern Medical University, 1838 Guangzhou Avenue, Baiyun, Guangzhou, Guangdong 510315, P.R. China

E-mail: luorc02@vip.163.com

E-mail: songxin68@126.com

*Contributed equally

Key words: curcumin, Toll-like receptor 4/MyD88, epidermal growth factor receptor, cell proliferation, epithelial-mesenchymal transition, non-small cell lung cancer
(TLR4)/MyD88 and EGFR in a dose- and time-dependent manner. Conversely, EGF reversed the inhibitory action of curcumin on TLR4/MyD88. In clinical specimens, TLR4 and MyD88 were highly expressed in NSCLC tissues, and a significant positive association was observed between TLR4 and MyD88 expression. These data suggested that curcumin may control the EGFR and TLR4/MyD88 pathways to synergistically downregulate downstream cell cycle- and EMT-related regulators, in order to block cell proliferation and metastasis in NSCLC. These findings provide evidence for the clinical application of curcumin.

\section{Introduction}

Lung cancer is a main cause of cancer-associated mortality worldwide. Non-small cell lung cancer (NSCLC) accounts for $\sim 80 \%$ of all lung cancer cases (1-4). Despite the rapid development in medical science in recent years, the prognosis of patients with NSCLC remains unsatisfactory, with an overall 5-year relative survival rate of only $18 \%$, which is reduced to $4 \%$ for metastatic cancer (4). Therefore, it is essential to seek a novel therapy, and to identify an exact signaling pathway or molecular target protein responsible for NSCLC proliferation and metastasis.

The principal constituents of turmeric extracts include curcumin, demethoxycurcumin, bisdemethoxycurcumin and cyclocurcumin (5). Among these compounds, curcumin has been the most extensively studied natural compound in the last few decades due to its pleiotropic effects on numerous molecular targets in different diseases (6-9). Previous studies regarding curcumin have mainly focused on its anti-inflammatory abilities, whereas its effective anticancer activity was not recognized until the early 1990s $(10,11)$.

The Toll-like receptor 4 (TLR4)/MyD88 pathway is a classic signaling pathway associated with inflammation. 
Cancer is closely related to inflammation, particularly chronic inflammation (12-15). Previous studies have reported that aberrant expression of TLR4 is involved in several types of human cancer, including gastric cancer (16), lung cancer (17), prostate cancer (18), glioblastoma (19) and colorectal cancer (20). However, the specific role of TLR4 in NSCLC cell proliferation and metastasis is currently unknown.

Epidermal growth factor receptor (EGFR) is a receptor tyrosine kinase, which is overexpressed or aberrantly activated in various cancer cells and regulates numerous complex pathological processes, including cell proliferation, differentiation, invasion and migration (21). A previous study reported that downregulation of EGFR by curcumin inhibits cell growth and induces apoptosis in NSCLC cells (22). Furthermore, several studies have detected intracellular cross talk between EGFR signaling and the TLR4 pathway (23-25). Research in gastric epithelial cells has demonstrated that TLR4 is able to transactivate the EGFR pathway through Helicobacter pylori protein HP0175, resulting in the pathophysiology of ulcerogenesis and/or carcinogenesis (24). Therefore, it was hypothesized that curcumin may suppress the proliferation and metastasis of NSCLC through the TLR4/MyD88 and EGFR pathways.

\section{Materials and methods}

Clinical samples. Tissue specimens were obtained from the Department of Pathology, The Third Affiliated Hospital of Kunming Medical University (Tumor Hospital of Yunnan Province) between May 2003 and July 2010. Specimens were fixed with $10 \%$ neutral formalin for $72 \mathrm{~h}$ at room temperature and were then embedded in paraffin. The specimens consisted of 52 primary NSCLC tumor tissues and 49 benign lung tissues. The NSCLC specimens were obtained from 52 patients: 40 with adenocarcinoma and 12 with squamous cell carcinoma, including 30 men and 22 women, with ages ranging between 34 and 70 years (mean age, 59 years). The benign lung tissues were obtained from 49 patients with benign pulmonary diseases: 29 men and 20 women, with ages ranging between 32 and 70 years (mean age, 57 years). All patients underwent primary tumor resection, and the majority also received lymph node dissection. Patients with a diagnosis of relapse who had received preoperative radiation, chemotherapy or biotherapy were excluded to avoid any alterations in tumor marker determination resulting from treatment. Patients diagnosed with multiple primary cancers in other organs or tissues were also excluded. The study was approved by the ethics committee of The Third Affiliated Hospital of Kunming Medical University, and all patients provided written informed consent and authorization for use of biological specimens. Demographic and clinical data were obtained from the patients' medical records.

Pathology. A routine histological examination was performed with hematoxylin-eosin staining at room temperature; the stained slices were reviewed independently by three pathologists under a light microscope. Benign lung tissues were collected from a normal section of the lung in patients with a benign pulmonary disease identified by pathologists. All carcinomas were classified in accordance with the 7 th edition of the American Joint Committee on Cancer staging system (26).
Immunohistochemistry (IHC). Samples were processed for immunohistochemical analysis, in order to detect TLR4 and MyD88 expression levels and distribution patterns. Briefly, $4-\mu \mathrm{m}$ sections of paraffin-embedded tissues were mounted on charged glass slides and baked at $70^{\circ} \mathrm{C}$ for $1 \mathrm{~h}$. The slides were allowed to cool to room temperature, deparaffinized in xylene and rehydrated in a graded alcohol series. Sections were then microwave-treated for $5 \mathrm{~min}$ in citrate buffer ( $\mathrm{pH}$ 6.0) for antigen retrieval, and endogenous peroxidase activity was blocked by incubation in $0.3 \%$ hydrogen peroxide for $20 \mathrm{~min}$ at room temperature. Mouse monoclonal TLR4 (cat.no.SAB1404475; Sigma-Aldrich; Merck KGaA) and rabbit monoclonal Myd88 (cat. no. ab133739; Abcam) antibodies were used to detect TLR4 and Myd88 protein expression, respectively, at 1:600 and 1:250 dilutions in PBS; sections were incubated with these antibodies at $4^{\circ} \mathrm{C}$ overnight. After two washes in PBS, slides were incubated with undiluted rabbit secondary antibodies from a Dako REAL EnVision detection system/Horseradish Peroxidase for rabbit/mouse secondary antibodies kit (cat. no. K5007; Agilent Technologies, Inc.) for $30 \mathrm{~min}$ at room temperature, The peroxidase reaction was developed using 3,3'-diaminobenzidine (DAB) chromogen solution (Dako; Agilent Technologies, Inc.). Sections were visualized with DAB and counterstained with hematoxylin for $2 \mathrm{~min}$ at room temperature. Sections were scored semi-quantitatively under a light microscope for the extent of the immunoreaction as follows: $0,0 \%$ immunoreactive cells; $1,<20 \%$ immunoreactive cells; 2, 20-50\% immunoreactive cells; and 3, >50\% immunoreactive cells. In addition, the intensity of staining was scored semi-quantitatively as 0 , negative; 1 , weak; 2 , intermediate; and 3, strong. The final immunoreaction score was defined as the sum of both parameters (extent and intensity), and samples were grouped according to the summed score as negative (0), weak staining (1-3), moderate staining (4-6) and strong staining (7-9). Final immunoreaction scores $>0$ were defined as positive. All slides were evaluated independently for protein expression by three separate observers; slides with an incongruent grading were scrutinized a second time, and a consensus was reached.

Cell lines. The NSCLC cell lines NCI-A549 (human lung adenocarcinoma) and NCI-H226 (human lung squamous cancer) were used in the present study. The H226 cell line was purchased from the Cell Bank of Chinese Academy of Sciences, and the A549 cell line was obtained from the American Type Culture Collection. A549 and H226 cells were respectively grown in DMEM F12 (Gibco; Thermo Fisher Scientific, Inc.) and RPMI-1640 (Gibco; Thermo Fisher Scientific, Inc.) supplemented with $10 \%$ fetal bovine serum (FBS; Gibco; Thermo Fisher Scientific, Inc.) and penicillin $(1,000 \mathrm{U} / \mathrm{ml}) /$ streptomycin $(10 \mathrm{mg} / \mathrm{ml})$ (cat. no. SV30010; Hyclone; GE Healthcare) at $37^{\circ} \mathrm{C}$ in an incubator containing $5 \% \mathrm{CO}_{2}$.

Cell treatment. For the dose response analysis, A549 and H226 cells were treated with different concentrations (A549, 5, 10, $15 \mu \mathrm{M} ; \mathrm{H} 226,5,10,20 \mu \mathrm{M}$ ) of curcumin for $72 \mathrm{~h}$ in a $37^{\circ} \mathrm{C}$ incubator containing $5 \% \mathrm{CO}_{2}$. For the analysis of time-dependent response, A549 and $\mathrm{H} 226$ cells were treated with curcumin $(10 \mu \mathrm{M})$ for various durations $(0,24,48$ and $72 \mathrm{~h})$. 
To investigate the signaling pathway, A549 and $\mathrm{H} 226$ cells were pretreated with either DMSO or curcumin $(10 \mu \mathrm{M})$ for $72 \mathrm{~h}$, followed by a $12-\mathrm{h}$ serum-starvation period. After the aforementioned treatments, cells were sequentially grown in an incubator with $5 \% \mathrm{CO}_{2}$ at $37^{\circ} \mathrm{C}$. EGF $(100 \mathrm{ng} / \mathrm{ml})$ was added to the cell culture dish at different time points $(1.5,3$ and $6 \mathrm{~h})$ after serum starvation. Following the application of the aforementioned treatments, cells were placed in an incubator with $5 \% \mathrm{CO}_{2}$ at $37^{\circ} \mathrm{C}$. Then, cells in the logarithmic growth phase were collected to perform western blot analysis.

Western blot analysis. Cells (A549 and H226) were harvested after drug treatment and lysed in RIPA buffer (cat. no. 89900; Pierce; Thermo Fisher Scientific, Inc.). The lysates were centrifuged at $12,000 \mathrm{x} \mathrm{g}$ for $20 \mathrm{~min}$ at $4^{\circ} \mathrm{C}$, and the supernatants were collected. Protein concentration was measured using the bicinchoninic acid assay (cat. no. 23227; Pierce; Thermo Fisher Scientific, Inc.). For each sample, $50 \mu \mathrm{g}$ protein lysate was loaded per well, and protein samples were separated by $10 \%$ SDS-PAGE and transferred onto polyvinylidene fluoride membranes (cat. no. ISEQ00010; EMD Millipore) by electroblotting. Membranes were pretreated with $8 \%$ non-fat dry milk in TBS-Tween-20 (0.05-0.1\%) (TBS-T) for $2 \mathrm{~h}$ at room temperature, followed by incubation with primary antibodies for $16 \mathrm{~h}$ at $4^{\circ} \mathrm{C}$. The primary antibodies used targeting the following proteins were diluted at 1:1,000 and were purchased from Abcam: Cyclin B1 (cat. no. ab72), cyclin A1 (cat. no. ab53699), cyclin A2 (cat. no. ab38), cyclin D1 (cat. no. ab6152), cyclin E1 (cat. no. ab3927), cyclin-dependent kinase (CDK)4 (cat. no. ab108357), CDK1 (cat. no. ab18), CDK6 (cat. no. ab124821), p21 (cat. no. ab109520), p15 (cat. no. ab94688), c-Jun (cat. no. ab32137), phosphorylated (p)-c-Jun Ser63 (cat. no. ab32385), JunB (cat. no. ab31421), p-JunB Ser259 (cat. no. ab30628), c-fos (cat. no. 190289), and p-c-fosSer32 (cat. no. ab79319). The epithelial-mesenchymal transition (EMT) antibody sampler kit (cat. no. 9782) was purchased from Cell Signaling Technology, Inc., and the primary antibodies were diluted at 1:1,000. The other primary antibodies, including TLR4 monoclonal antibody (cat. no. 66350-1-Ig), MyD88 monoclonal antibody (cat. no. 66660-1-Ig), the LY96/MD2 polyclonal antibody (cat. no. 11784-1-AP), EGFR rabbit monoclonal antibody (cat. no. 4405) and p-EGFR (Tyr1068) mouse monoclonal antibody (cat. no. 2236), were obtained from ProteinTech Group, Inc. and were diluted at 1:1,000. Following primary antibody incubation, the membranes were washed three times with TBS-T. Subsequently, the membranes were incubated with horseradish peroxidase-labeled secondary antibody $(1: 10,000$; cat. nos. 7076 and 7074; Cell Signaling Technology, Inc.) for $1 \mathrm{~h}$, prior to detection using an ECL reagent (cat. no. RPN2135; GE Healthcare); all blots were exposed for the same duration (5 min). $\alpha$-tubulin was used as an internal loading control (1:1,000; cat. no. 2125; Cell Signaling Technology, Inc.). Blots were semi-quantified using Gel-Pro Analyzer, version 4.0 (Media Cybernetics, Inc.).

MTS assay. Cell proliferation was determined using the MTS assay. Briefly, $2 \times 10^{3}$ cells/well were plated in 96 -well culture plates in $150 \mu 1$ medium; six parallel wells were assigned to each group, as well as a negative control (without cells). Over a 5-day period, $30 \mu \mathrm{l}$ MTS substrate was added to each well every $24 \mathrm{~h}$ and incubated for $2 \mathrm{~h}$ at $37^{\circ} \mathrm{C}$ in the dark. Absorbance was measured at $490 \mathrm{~nm}$ for each sample using a plate reader (BMG Labtech). The half maximal inhibitory concentration $\left(\mathrm{IC}_{50}\right)$ values were calculated from survival curves using the Bliss method (27). All experiments were performed three times independently.

Flow cytometric analysis. Following treatment with curcumin, cells were harvested using $0.1 \%$ trypsin/EDTA and washed three times with cold PBS by centrifugation at $300 \mathrm{xg}$ for $5 \mathrm{~min}$. For cell cycle analysis, cells were fixed in pre-chilled $70 \%$ ethanol overnight at $4^{\circ} \mathrm{C}$. The fixed cells were collected, washed twice with PBS, suspended in staining buffer (cat. no. C1052-1; Cell Cycle and Apoptosis Analysis Kit; Beyotime Institute of Biotechnology) containing $10 \mu \mathrm{g} / \mathrm{ml}$ propidium iodide (20X, cat. no. C1052-2; Beyotime Institute of Biotechnology) and $100 \mu \mathrm{g} / \mathrm{ml}$ RNase A (50X, cat. no. C1052-2; Beyotime Institute of Biotechnology), and then incubated at $37^{\circ} \mathrm{C}$ for $\geq 30 \mathrm{~min}$ in the dark to eliminate intracellular RNA. Analysis was performed on a FACSAria system (BD Biosciences) and data were analyzed using CellQuest software (version 5.1; BD Biosciences). All of the samples were assessed three times.

Colony formation assay. A549 cells were seeded into 6-well plates at a density of 100 cells/well. The medium containing curcumin $(5,10$ and $15 \mu \mathrm{M})$ and 10\% FBS was changed every 3 days. After 2 weeks, colonies resulting from the surviving cells were fixed with $3.7 \%$ methanol for $30 \mathrm{~min}$, stained with $10 \%$ Giemsa for $15 \mathrm{~min}$ at room temperature and counted. H226 cells were plated into 6-well plates at a density of 300 cells/well and were cultured in 10\% FBS and medium containing curcumin $(5,10$ and $20 \mu \mathrm{M})$. Similarly, the medium was also changed every 3 days. After 3 weeks, the developed colonies were fixed with $3.7 \%$ methanol and stained with Giemsa. Finally, colonies containing $\geq 50$ cells were counted. Each assay was performed in triplicate.

Transwell migration assay. The Transwell migration assay was used to determine the migratory ability of cells. Briefly, A549 cells were grown in DMEM F12 containing 10\% FBS and curcumin $(5$ and $10 \mu \mathrm{M})$. After $48 \mathrm{~h}$, the cells were harvested by trypsinization and washed once with PBS. To measure cell migration, $8-\mu \mathrm{m}$ pore size culture inserts (Costar; Corning Incorporated) were placed into the wells of 24-well culture plates, separating the upper and the lower chambers. In the lower chamber, $500 \mu 1$ DMEM F12 containing 10\% FBS was added, which was used as a chemoattractant. Subsequently, serum-free medium containing $1 \times 10^{5}$ cells/well was added to the upper chamber for migration assays. After 7-8 $\mathrm{h}$ of incubation at $37^{\circ} \mathrm{C}$ in an atmosphere containing $5 \% \mathrm{CO}_{2}$, the cells on the upper surface of the membrane were removed using a cotton swab, and the cells that had migrated through the pores were fixed with $3.7 \%$ methanol for $30 \mathrm{~min}$ and stained with hematoxylin for $5 \mathrm{~min}$ at room temperature. Finally, cell migration was determined by calculating the number of migrated cells in three visual fields per well by light microscopy (Olympus Corporation) at x100 magnification. Each experiment was performed at least three times. 
Statistical analysis. Data are presented as the mean \pm standard deviation. SPSS software for Windows (version 18.0; SPSS, Inc.) was used for statistical analysis. The association between TLR4 or MyD88 expression and clinicopathological parameters was analyzed by $\chi^{2}$ test, and contingency coefficient test was used to assess the association between TLR4 and MyD88. One-way ANOVA was used to analyze multiple groups, followed by post hoc analysis using Student-Newman-Keuls test for comparison between any two groups or Dunnett's test for comparison among experimental groups and the control group. Log-rank test was used for survival analysis. The hazard ratio was determined using Cox regression. The Kaplan-Meier Plotter (www.kmplot.com) was used to estimate the survival probability of TLR4 and MyD88 in NSCLC. P $<0.05$ was considered to indicate a statistically significant difference.

\section{Results}

Curcumin inhibits NSCLC cell proliferation and colony formation in vitro. Curcumin is a low molecular weight (368.39 Da) polyphenol, the chemical structure of which is shown in Fig. 1A. To investigate the effect of curcumin on NSCLC cell proliferation, the $\mathrm{IC}_{50}$ was determined in A549 and $\mathrm{H} 226$ cells from a dose-response curve after $72 \mathrm{~h}$ of treatment. The $\mathrm{IC}_{50}$ values of curcumin were 19.71 and $30.88 \mu \mathrm{M}$ in A549 and H226 cells, respectively (Fig. 1B and C). According to these results, $15 \mu \mathrm{M}$ curcumin caused a $20-30 \%$ decrease in A549 cell survival rate; a similar decrease was found in $\mathrm{H} 226$ cells in response to $20 \mu \mathrm{M}$ curcumin. Subsequently, the MTS assay and colony formation assay were conducted to evaluate the proliferation of NSCLC cells treated with 5, 10 and $15 \mu \mathrm{M}$, or 5, 10 and $20 \mu \mathrm{M}$ curcumin. As shown in Fig. 1D and E, treatment with curcumin for 4 days significantly reduced cell proliferation in a dose-dependent manner. Subsequently, the colony formation assay detected fewer colonies in the curcumin-treated groups compared with in the DMSO group (Fig. 1F and G). These data suggested that curcumin may inhibit cell proliferation in NSCLC.

Curcumin induces $G_{2} / M$ phase cell cycle arrest in NSCLC cell lines. To better understand the mechanism by which curcumin inhibited cell proliferation, the present study further analyzed the effects of curcumin on cell cycle distribution in A549 and H226 cells by flow cytometry. The proportion of cancer cells in $G_{2} / M$ phase was significantly increased in the curcumin-treated groups compared with in the DMSO group in A549 cells, and the proportion of cells in $\mathrm{G}_{0} / \mathrm{G}_{1}$ phase was concomitantly decreased (Fig. 2A and C). However, in H226 cells, 5 and $10 \mu \mathrm{M}$ curcumin produced very little change in all phases of the cell cycle. However, $20 \mu \mathrm{M}$ curcumin markedly increased the population of cells in $G_{2} / M$ phase (Fig. 2B and D). These data indicated that curcumin may modulate $\mathrm{G}_{2} / \mathrm{M}$ transition in the cell cycle progression of NSCLC cells.

The cell cycle process is well known to be controlled by several types of checkpoints, including cyclins, CDKs and CDK inhibitors (CDKIs) (28). To explain the molecular mechanism by which curcumin induced $\mathrm{G}_{2} / \mathrm{M}$ phase arrest, the expression of various cell cycle checkpoints were detected. The results demonstrated that the protein expression levels of the cell cycle promoters cyclin A1, cyclin A2, cyclin B1, cyclin E1, cyclin D1 and CDK1 were markedly decreased, whereas the expression levels of CDKIs, including p15 and p21, were significantly upregulated (Figs. 2E, and S1A and B). Activator protein-1 (AP-1) has been reported to be closely associated with the proliferation of tumor cells (29), and activation of c-Jun and JunD stimulate cyclin D1 $(30,31)$. Therefore, this study examined the alteration in AP-1 and observed an obvious decrease in the protein expression levels of c-Jun and c-fos, as well as phosphorylation on c-Jun Ser63 and c-fos Ser32 (Figs. 2F and S1C). These findings indicated that curcumin may slow cell cycle progression by downregulating interrelated cyclins and CDKs modulated by c-Jun and c-Fos. However, no significant differences were observed in CDK4, CDK6, JunB and p-JunB Ser259 expression, thus suggesting that these signaling molecules were not affected by curcumin.

Briefly, these data indicated that curcumin may serve a key role in modulating the cell cycle transition in NSCLC via altering the protein expression levels of c-Jun and c-fos, thereby further affecting cell cycle regulators, including cyclins (cyclin A1, cyclin A2, cyclin B1, cyclin E1 and cyclin D1) and CDK1.

Curcumin suppresses NSCLC cell migration via EMT-related proteins. A Transwell migration assay was conducted to study the effects of curcumin on NSCLC cell migration. As shown in Fig. 3A and B, the number of migrated A549 and H226 cells in the curcumin-treated group was markedly decreased compared with in the DMSO-treated group, which indicated that curcumin may exert anti-metastatic effects. Subsequently, alterations in EMT-related proteins were detected and E-cadherin was revealed to be markedly upregulated, whereas vimentin was markedly downregulated in the curcumin-treated group (Figs. 3 and S2). Furthermore, the expression levels of transcription factors associated with E-cadherin, including transcription factor 8 (TCF8), Snail and Slug, were determined. In line with our expectations, the expression levels of these transcription factors were markedly decreased in response to curcumin treatment (Figs. 3 and S2). These findings suggested that curcumin inhibited NSCLC cell migration via EMT-related proteins.

Curcumin downregulates the expression levels of TLR4/MyD88 and EGFR. TLR4 and EGFR are not only membrane receptors but also upstream effectors of the AP-1 protein (32). The present study detected MD-2, TLR4, MyD88 and EGFR protein expression using western blot analysis. It has previously been reported that curcumin regulates the TLR4/MyD88 signaling pathway by affecting MD-2 expression (33). Consistently, when cultured with curcumin, A549 and H226 cells exhibited a dose-dependent inhibition of MD-2, MyD88 and EGFR protein levels. Notably, TLR4 was significantly inhibited by curcumin in H226 cells; however, only a non-significant downward trend in TLR4 was detected in response to curcumin in A549 cells (Figs. 4A and B, and S3A and B). In addition, a time-dependent significant decrease in TLR4, MyD88 and EGFR protein expression was detected following curcumin treatment in vitro (Figs. 4C and D, and S3C and D). These results indicated that curcumin inhibited the TLR4/MyD88 and EGFR signaling pathways in NSCLC cells. 
A<smiles>COc1cc(/C=C/C(=O)CC(=O)/C=C/c2ccc(O)c(OC)c2)ccc1O</smiles>

B

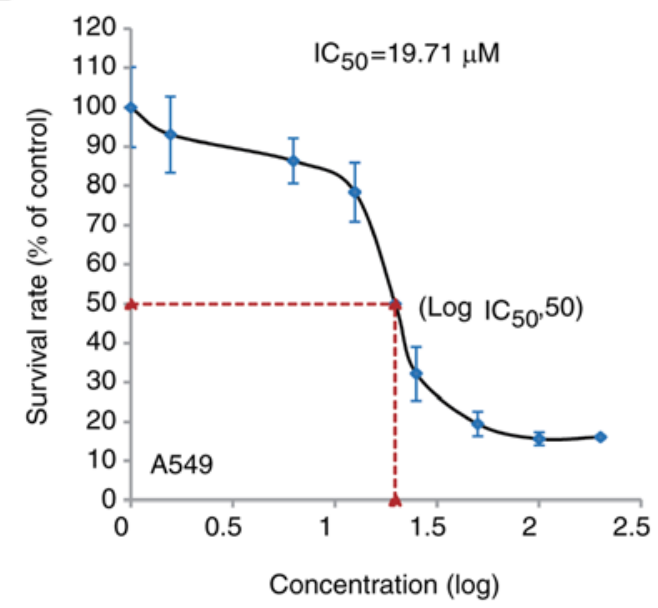

D

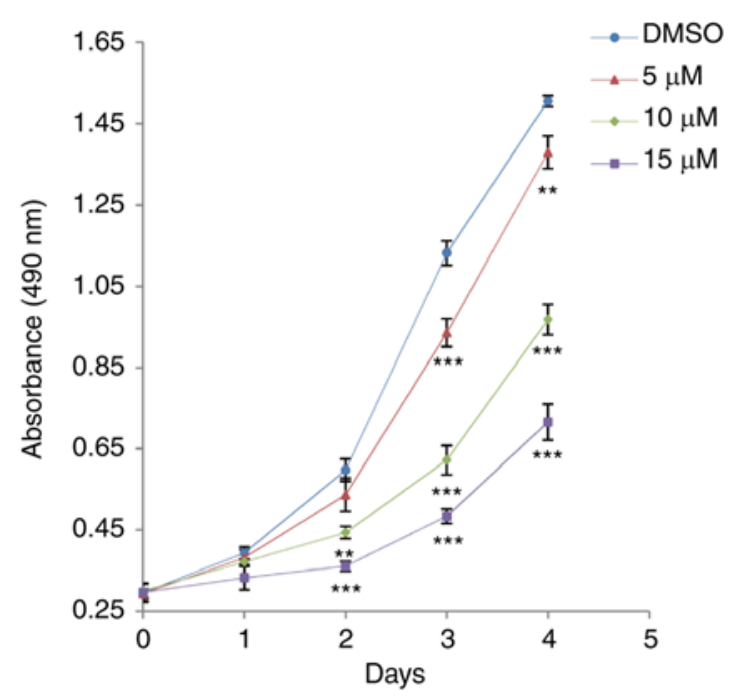

F

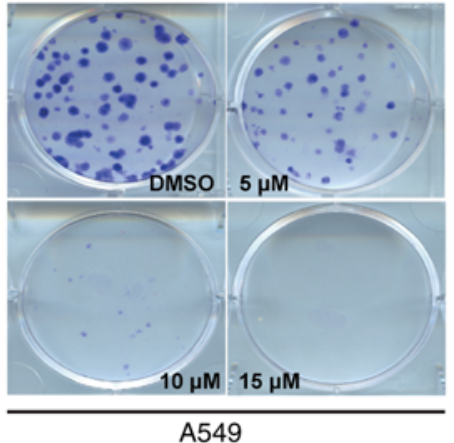

Curcumin

C

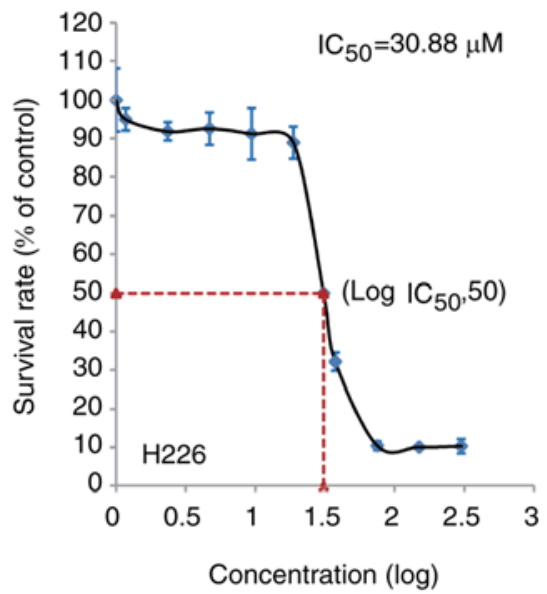

E

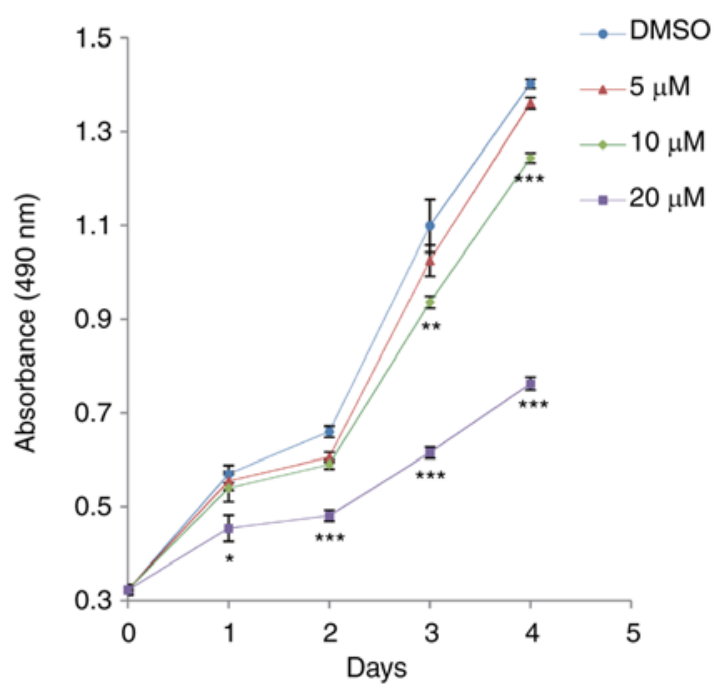

G

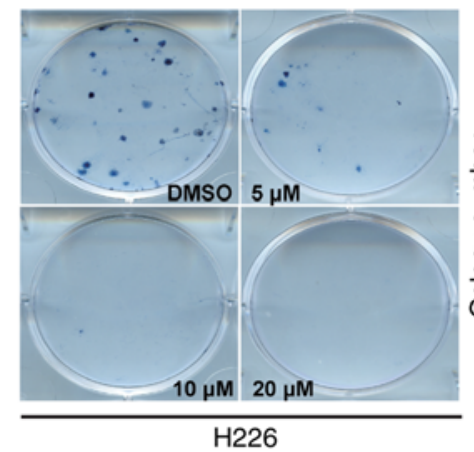

Figure 1. Curcumin inhibits cell proliferation in NSCLC cell lines. (A) Chemical structure and formula of curcumin. (B) A549 and (C) H226 cells were treated with serial concentrations of curcumin for $72 \mathrm{~h}$. An MTS assay was used to determine the proliferation of A549 and H226 cells. (D) A549 and (E) H226 cells were cultured with different doses of curcumin, and an MTS assay was used to detect cell proliferation at the same time point each day. (F and G) Colony formation assay indicated that curcumin significantly inhibited colony formation in (F) A549 and (G) H226 cells. Cells were treated with various doses of curcumin and colonies were counted after 2 weeks (A549) or 3 weeks (H226) using Giemsa staining. Data are presented as the mean \pm standard deviation. ${ }^{*} \mathrm{P}<0.05,{ }^{* *} \mathrm{P}<0.01,{ }^{* * *} \mathrm{P}<0.001$ vs. the DMSO group. $\mathrm{IC}_{50}$, half maximal inhibitory concentration. 
A
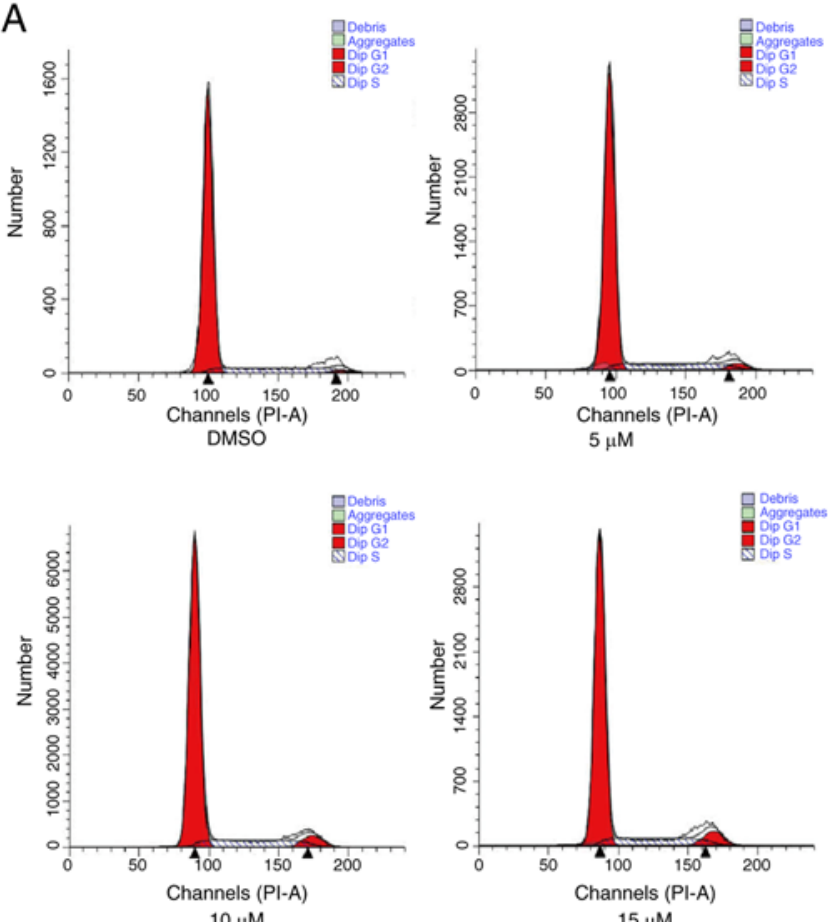

$10 \mu \mathrm{M}$

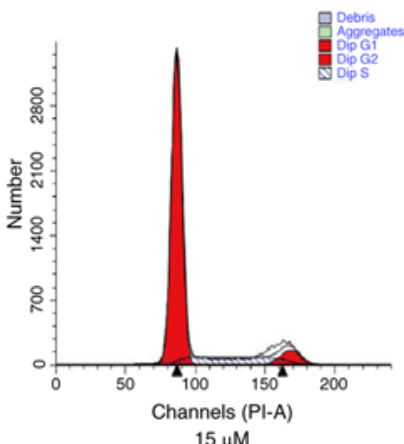

$15 \mu \mathrm{M}$
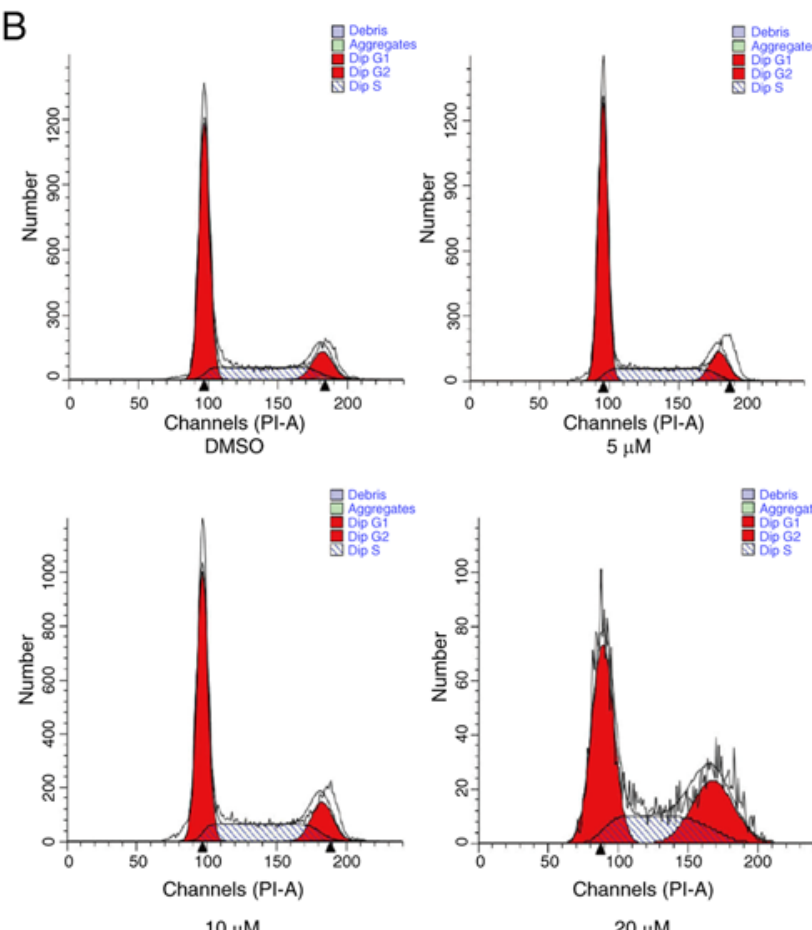

$10 \mu \mathrm{M}$

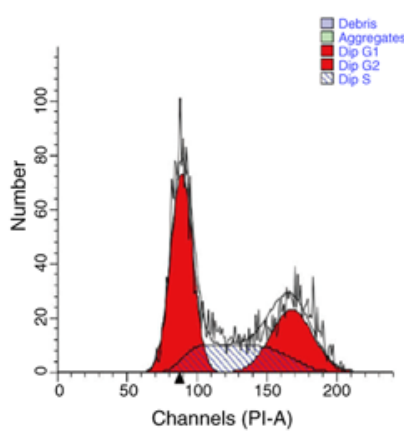

$20 \mu \mathrm{M}$

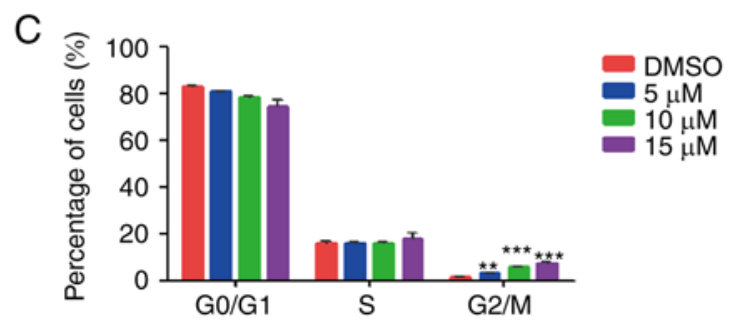

$\mathrm{D}$
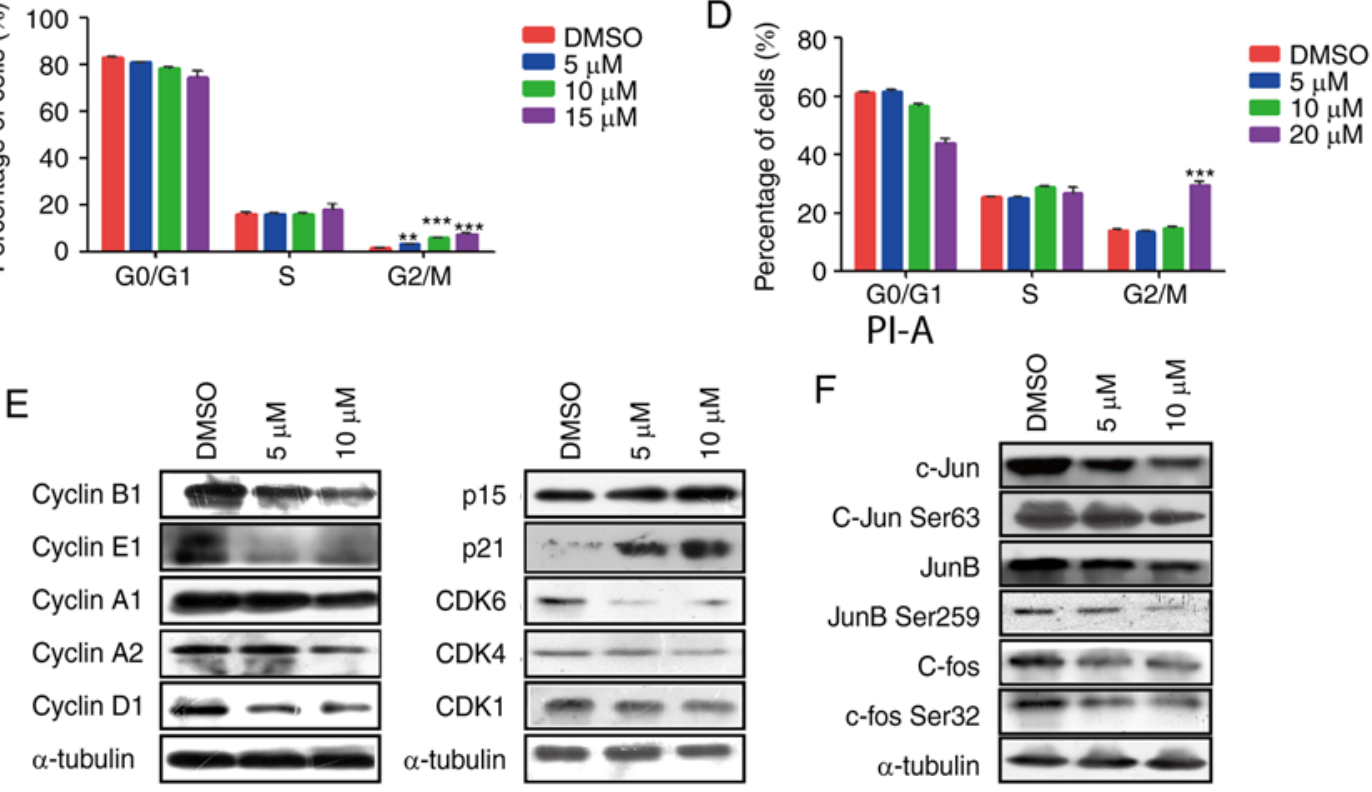

$\mathrm{F}$
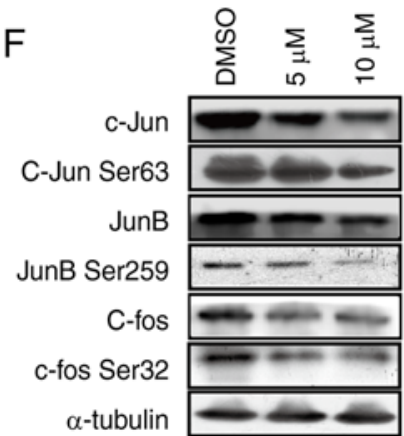

Figure 2. Effects of curcumin on the cell cycle progression of NSCLC cell lines. Flow cytometric analysis and quantification of the cell cycle progression in (A and C) A549 and (B and D) H226 cells treated with curcumin at different concentrations. ${ }^{* *} \mathrm{P}<0.01$ and ${ }^{* * *} \mathrm{P}<0.001$ vs. the DMSO group. (E) Western blotting revealed that treatment of A549 cells with curcumin affected the expression of numerous cell cycle-related proteins, including cyclins, CDKs and CDK inhibitors. $\alpha$-tubulin was used as a loading control. (F) Western blotting revealed that treatment of A549 cells with curcumin affected the expression and phosphorylation of Jun family members, including c-Jun, JunB and c-fos. $\alpha$-Tubulin was used as a loading control. CDK, cyclin-dependent kinase.

EGF reverses the inhibitory effects of curcumin on TLR4/MyD88 in NSCLC cells. Studies regarding the interactions between TLR4 and EGFR are emerging; however, the underlying mechanism remains unclear. A lack of a physical association between TLR4 and EGFR has been demonstrated by coimmunoprecipitation assays in mouse macrophage cells, and EGFR requires the participation of Lyn kinase to activate the TLR4 signaling pathway in mouse septic shock (34). Therefore, whether there is a synergistic relationship between EGFR and TLR4 in curcumin-treated NSCLC cells, and whether TLR4/MyD88 is downstream of EGFR, is currently unknown. This study aimed to determine whether cross talk existed between TLR4 and EGFR in curcumin-treated NSCLC cells. For this purpose, A549 and H226 cells were treated successively with DMSO or curcumin $(10 \mu \mathrm{M})$ and EGF $(100 \mathrm{ng} / \mathrm{ml})$. Western blotting revealed that EGF significantly promoted MyD88 expression, and EGF also recovered MyD88 expression in curcumin-treated A549 cells. Conversely, the inhibitory effect of curcumin on TLR4 was slight and the difference was not statistically significant in A549 cells. In 
A
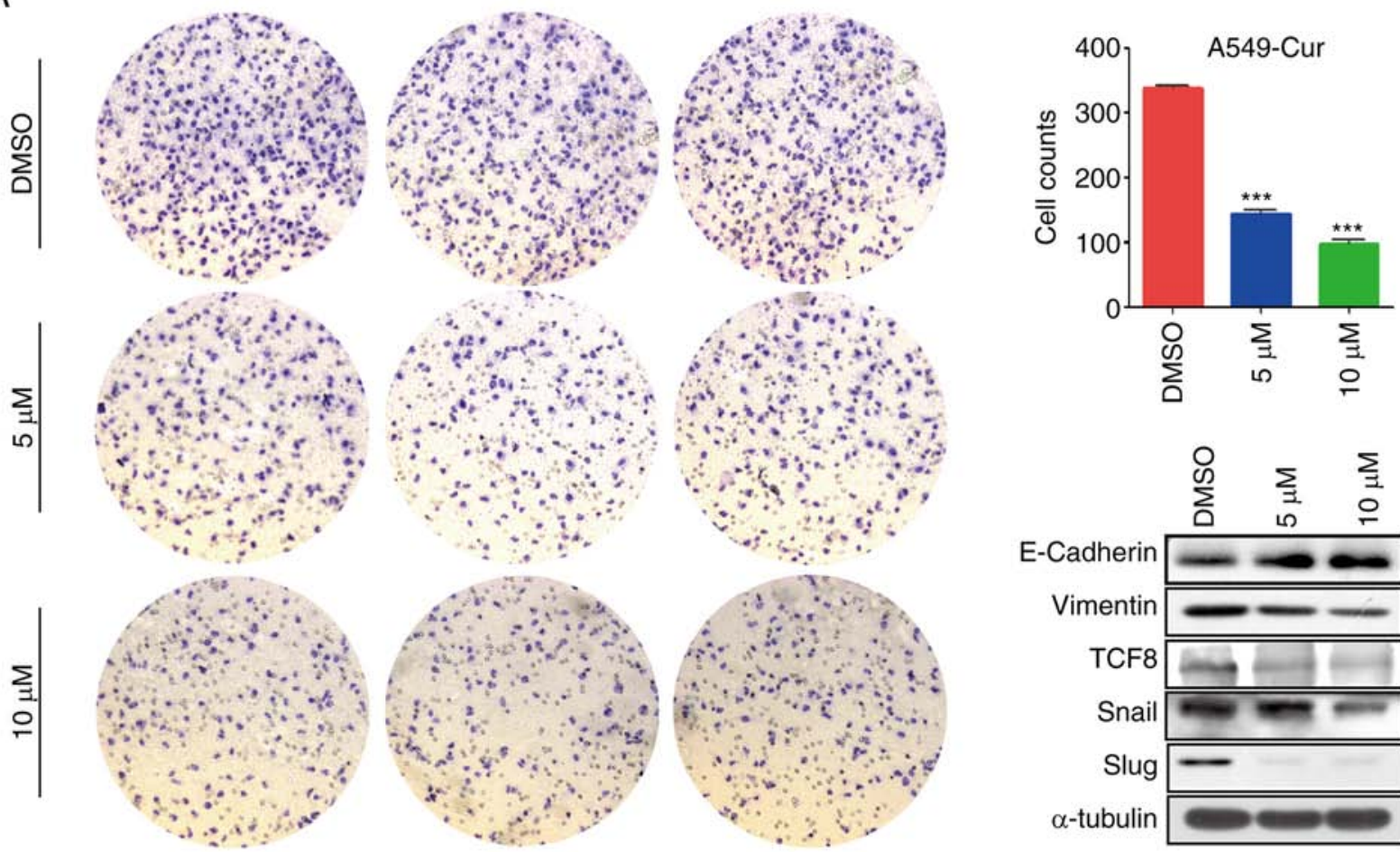

B
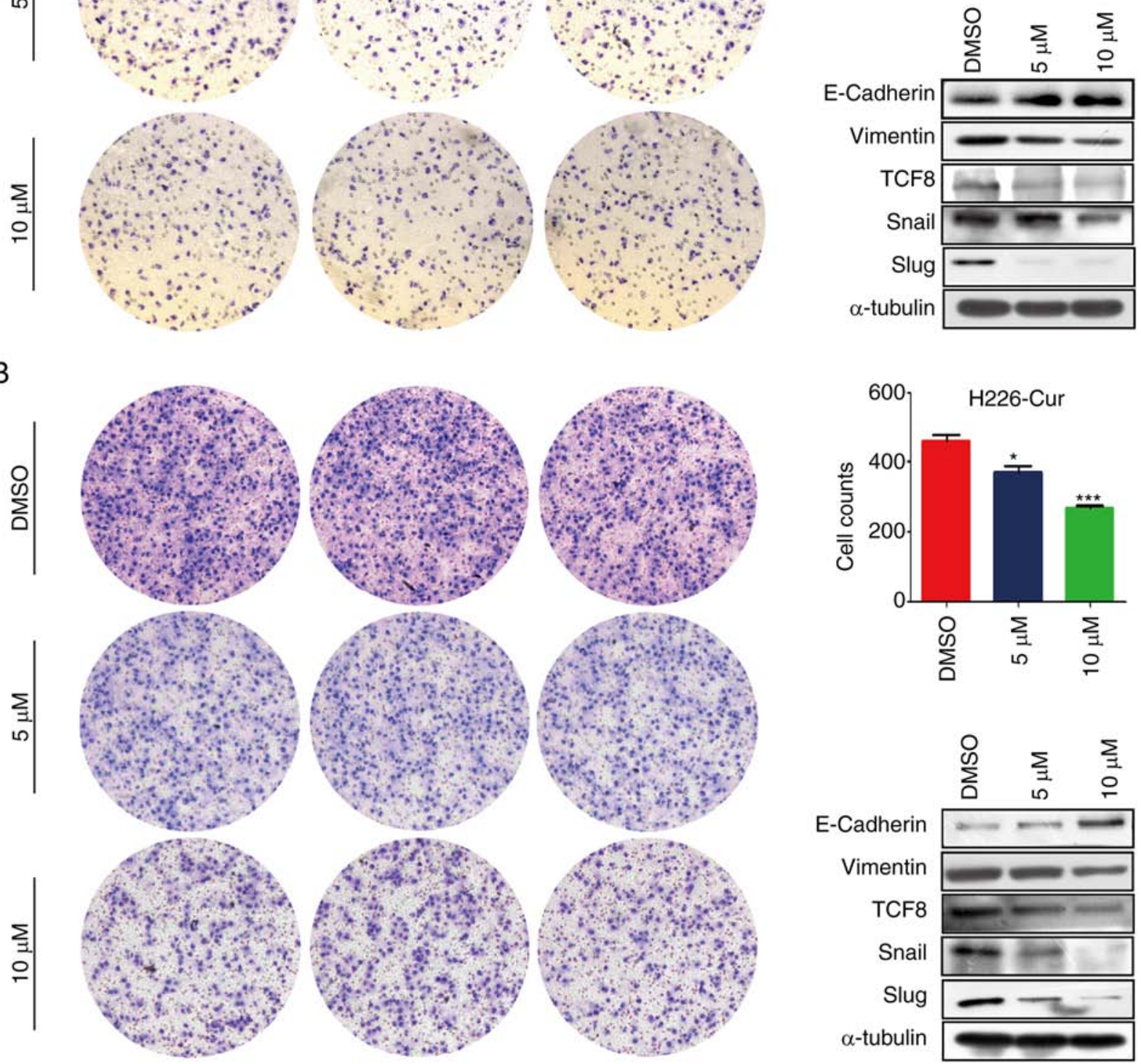

Figure 3. Curcumin inhibits the migratory ability of A549 and H226 cells. Curcumin decreased cell migration in (A) A549 and (B) H226 cells in vitro. Western blotting revealed that curcumin regulated epithelial-mesenchymal transition-related proteins, including E-cadherin, vimentin, TCF8, Snail and Slug, which may impact cell migration. ${ }^{*} \mathrm{P}<0.05$ and ${ }^{* * *} \mathrm{P}<0.001$ vs. the DMSO group. TCF8, transcription factor 8.

addition, no significant difference in TLR4/MyD88 expression was detected in H226 cells. Furthermore, EGF significantly promoted p-EGFR expression and could recover p-EGFR levels in curcumin-treated NSCLC cells (Figs. 4E and F, and S3E and F). These results indicated that the TLR4/MyD88 and EGFR pathways may synergistically regulate cell proliferation and migration in curcumin-treated NSCLC cells.
TLR4/MyD88 expression is upregulated in NSCLC tissues. The present study examined the expression levels of TLR4/MyD88 in 52 NSCLC tissue samples and 49 benign lung tissue samples. The panels presented in Fig. 5 are representative images of TLR4 and MyD88 expression in lung adenocarcinoma and benign lung tissues. TLR4-positive staining and MyD88-positive staining were confined mainly to the cytomembrane and 
A

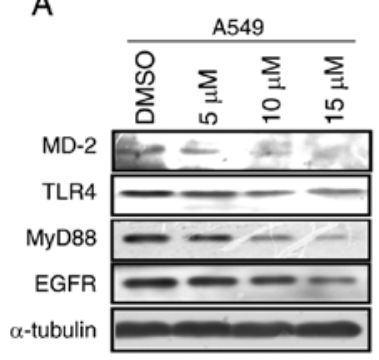

C

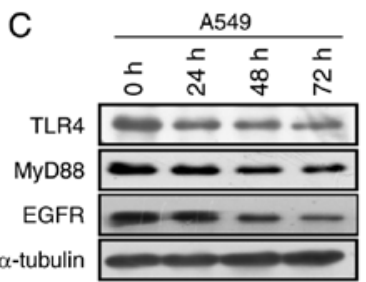

B
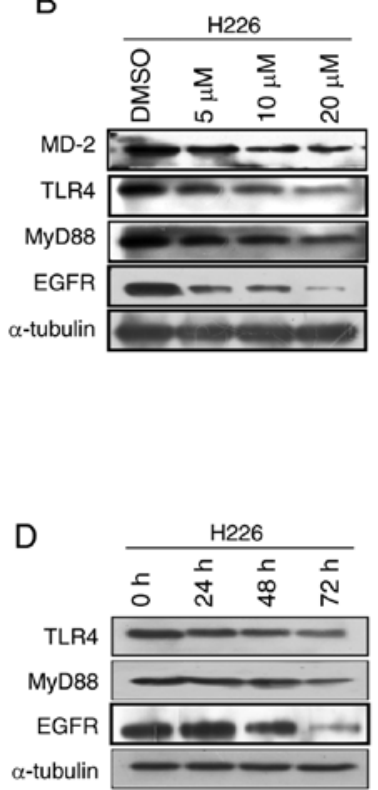
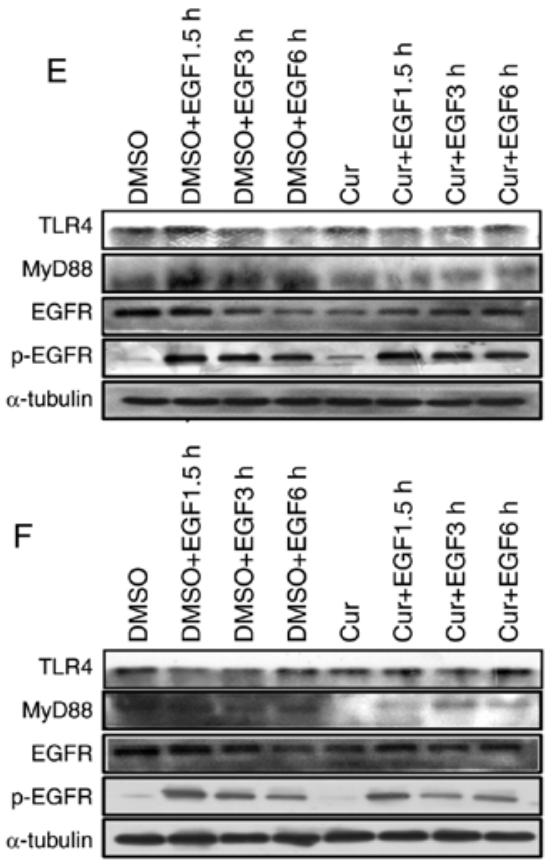

Figure 4. Curcumin treatment inhibits the proliferation of NSCLC cells by affecting the TLR4/MyD88 and EGFR signaling pathways. (A) A549 and (B) H226 cells were treated with different concentrations of curcumin for $72 \mathrm{~h}$. MD-2, TLR4, MyD88 and EGFR levels were evaluated by western blotting. (C) A549 and (D) H226 cells were treated with curcumin $(10 \mu \mathrm{M})$ for various durations. TLR4, MyD88 and EGFR levels were determined by western blotting. (E) A549 and $(\mathrm{F}) \mathrm{H} 226$ cells were pretreated with either DMSO or curcumin $(10 \mu \mathrm{M})$ for $72 \mathrm{~h}$ and then underwent a 12-h serum-starvation period. EGF (100 ng/ml) was added to the cell culture dish at different time points after serum starvation. TLR4/MyD88 and EGFR levels were measured by western blotting. $\alpha$-tubulin was used as the loading control. EGF, epidermal growth factor; EGFR, EGF receptor; p-, phosphorylated; TLR4, Toll-like receptor 4.

A

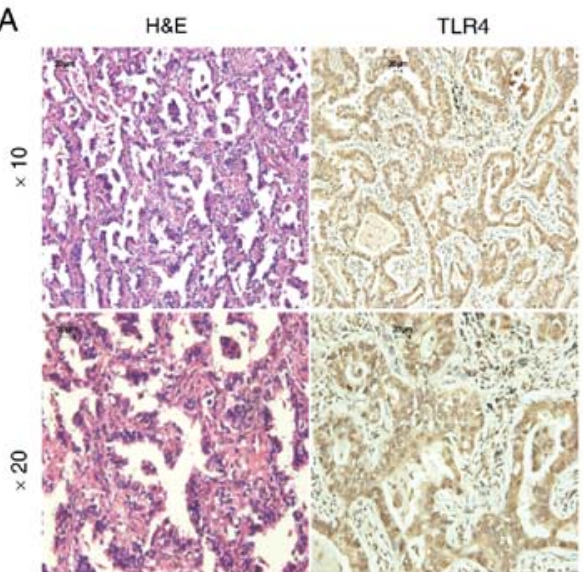

C

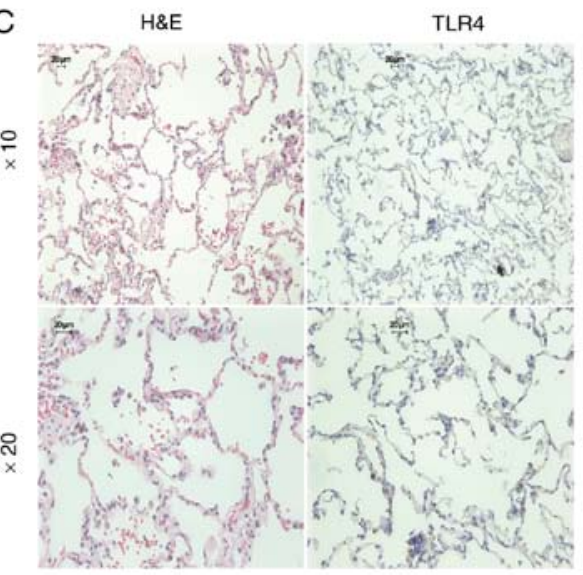

B

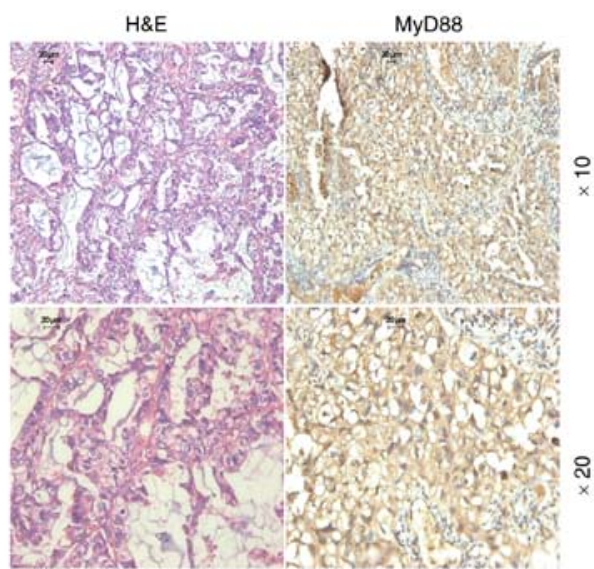

D

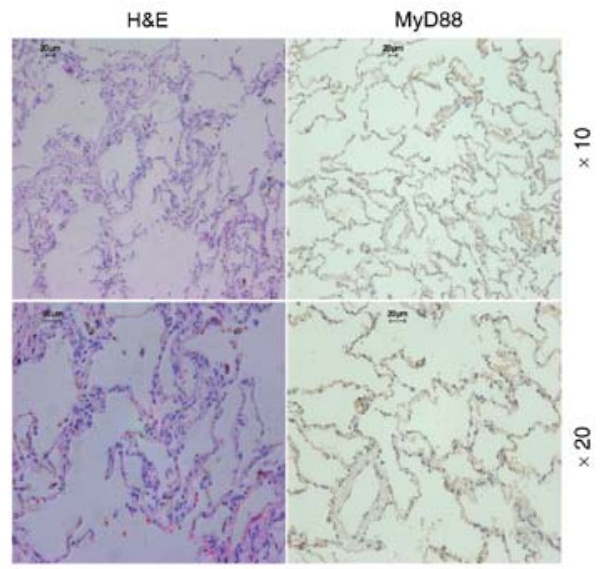

Figure 5. TLR4 and MyD88 are upregulated in non-small cell lung cancer tissues. H\&E and immunohistochemical staining of (A) TLR4 and (B) MyD88 in lung adenocarcinoma tissue. H\&E and immunohistochemical staining of (C) TLR4 and (D) MyD88 in benign lung tissue. Magnification, x10 and x20; scale bar, $20 \mu \mathrm{m}$. H\&E, hematoxylin and eosin; TLR4, Toll-like receptor 4. 
Table I. Association between clinicopathological factors and Toll-like receptor 4 expression in non-small cell lung cancer.

\begin{tabular}{|c|c|c|c|}
\hline Characteristic & No. of samples & No. of positive samples (\%) & P-value \\
\hline \multicolumn{4}{|l|}{ Histological type } \\
\hline Benign lung tissues & 49 & $10(20.4)$ & \multirow[t]{2}{*}{$<0.001$} \\
\hline Lung cancer tissues & 52 & $38(73.1)$ & \\
\hline \multicolumn{4}{|l|}{ Age (years) } \\
\hline$<60$ & 33 & $23(69.7)$ & \multirow[t]{2}{*}{0.469} \\
\hline$\geq 60$ & 19 & $15(79.0)$ & \\
\hline \multicolumn{4}{|l|}{$\operatorname{Sex}$} \\
\hline Male & 30 & $20(66.7)$ & \multirow[t]{2}{*}{0.224} \\
\hline Female & 22 & $18(81.8)$ & \\
\hline \multicolumn{4}{|l|}{ Pathology } \\
\hline Squamous cell carcinoma & 12 & $8(66.7)$ & \multirow[t]{2}{*}{0.568} \\
\hline Adenocarcinoma & 40 & $30(75.0)$ & \\
\hline \multicolumn{4}{|c|}{ Histopathological differentiation } \\
\hline Poor & 19 & $11(57.9)$ & \multirow[t]{3}{*}{0.158} \\
\hline Moderate & 19 & $15(78.9)$ & \\
\hline High & 14 & $12(85.7)$ & \\
\hline \multicolumn{4}{|l|}{ Tumor size } \\
\hline $\mathrm{T} 1 / \mathrm{T} 2$ & 45 & $33(73.3)$ & \multirow[t]{2}{*}{0.916} \\
\hline $\mathrm{T} 3 / \mathrm{T} 4$ & 7 & $5(71.4)$ & \\
\hline \multicolumn{4}{|l|}{ Lymph node metastasis } \\
\hline N0 & 21 & $16(76.2)$ & \multirow[t]{2}{*}{0.677} \\
\hline N1-2 & 31 & $22(71.0)$ & \\
\hline \multicolumn{4}{|l|}{ Pathological stage } \\
\hline I-IIB & 35 & $24(68.6)$ & \multirow[t]{2}{*}{0.293} \\
\hline IIIA-IIIB & 17 & $14(82.4)$ & \\
\hline
\end{tabular}

cytoplasm in NSCLC tissue (Fig. 5A and B), whereas benign lung tissue was negatively or weakly stained (Fig. 5C and D). TLR4-positive staining was detected in 38 out of $52(73.1 \%)$ NSCLC samples but only in 10 out of 49 (20.4\%) benign lung tissue samples $(\mathrm{P}<0.001$; Table I). Similarly, MyD88-positive staining was detected in 28 out of $52(53.8 \%)$ NSCLC samples but was only found in 12 out of $49(24.5 \%)$ benign lung tissue samples $(\mathrm{P}=0.003$; Table II). However, there was no association between TLR4/MyD88 expression and numerous clinical characteristics, including sex, age, histological type, differentiation, tumor size, lymph node metastasis and pathological stage. Notably, the contingency coefficient analysis between TLR4 and MyD88 expression exhibited a significant positive association $(\phi=0.308, \mathrm{P}=0.026$; Table III).

TLR4/MyD88 expression and EGFR expression may be relevant to the survival of patients with NSCLC. The follow-up period for all 52 patients (I-IIB stage) enrolled in this research began at the discharge date until September 2015. At the end of the follow-up period, six patients were lost to follow-up and 24 had died, leaving 22 survivors. By differentiating patients into positive or negative TLR4/MyD88 staining groups, the prognostic effect of TLR4/MyD88 on the overall survival of patients with NSCLC was analyzed. Kaplan-Meier curve analysis demonstrated that there was no association between TLR4/MyD88 staining status and overall survival $(\mathrm{OS})$ of patients with $\operatorname{NSCLC}(\mathrm{n}=52 ; \mathrm{P}=0.795$ and 0.630 , respectively; Fig. $6 \mathrm{~B}$ and D). However, this result differed from the results of Kaplan-Meier data analysis on a larger sample size. As shown in Fig. 6A and C, these results suggested that TLR4/MyD88 expression levels were significantly associated with OS in patients with NSCLC. Of the possible reasons for this disagreement, one may be the small sample size $(n=52)$. Similarly, the Kaplan-Meier Plotter database was used to analyze the association between EGFR expression and OS. The results shown in Fig. S4 suggested that high EGFR expression was closely associated with poor prognosis.

\section{Discussion}

The currently available treatments for NSCLC have poor curative effects, which are an obstacle to therapy; therefore, the development of safe and effective therapies is urgently required to improve treatment. Tumorigenesis is usually accompanied by aberrant alterations in the expression levels of gene involved in cell proliferation and metastasis. As a promising anticancer agent, curcumin targets multiple signaling pathways and regulates the expression of genes related to tumor signal transduction (35). 
Table II. Association between the clinicopathological factors and MyD88 expression in non-small cell lung cancer.

\begin{tabular}{|c|c|c|c|}
\hline Characteristic & No. of samples & No. of positive samples (\%) & P-value \\
\hline \multicolumn{4}{|l|}{ Histological type } \\
\hline Benign lung tissues & 49 & $12(24.5)$ & \multirow[t]{2}{*}{0.003} \\
\hline Lung cancer tissues & 52 & $28(53.8)$ & \\
\hline \multicolumn{4}{|l|}{ Age, years } \\
\hline$<60$ & 33 & $16(48.5)$ & \multirow[t]{2}{*}{0.307} \\
\hline$\geq 60$ & 19 & $12(63.2)$ & \\
\hline \multicolumn{4}{|l|}{ Sex } \\
\hline Male & 30 & $18(60.0)$ & \multirow[t]{2}{*}{0.299} \\
\hline Female & 22 & $10(45.5)$ & \\
\hline \multicolumn{4}{|l|}{ Pathology } \\
\hline Squamous cell carcinoma & 12 & $8(66.7)$ & \multirow[t]{2}{*}{0.310} \\
\hline Adenocarcinoma & 40 & $20(50.0)$ & \\
\hline \multicolumn{4}{|c|}{ Histopathological differentiation } \\
\hline Poor & 19 & $8(42.1)$ & \multirow[t]{3}{*}{0.411} \\
\hline Moderate & 19 & $12(63.2)$ & \\
\hline High & 14 & $8(57.1)$ & \\
\hline \multicolumn{4}{|l|}{ Tumor size } \\
\hline $\mathrm{T} 1 / \mathrm{T} 2$ & 45 & $24(53.3)$ & \multirow[t]{2}{*}{0.851} \\
\hline $\mathrm{T} 3 / \mathrm{T} 4$ & 7 & $4(57.1)$ & \\
\hline \multicolumn{4}{|l|}{ Lymph node metastasis } \\
\hline N0 & 21 & $10(47.6)$ & \multirow[t]{2}{*}{0.458} \\
\hline N1-2 & 31 & $18(58.1)$ & \\
\hline \multicolumn{4}{|l|}{ Pathological stage } \\
\hline I-IIB & 35 & $19(54.3)$ & \multirow[t]{2}{*}{0.927} \\
\hline IIIA-IIIB & 17 & $9(52.9)$ & \\
\hline
\end{tabular}

Table III. Association between TLR4 and MyD88 expression in non-small cell lung cancer tissues.

\begin{tabular}{lrrrrr}
\hline & \multicolumn{2}{c}{ MyD88 } & & \\
\cline { 2 - 3 } TLR4 & + & - & & P-value & $\phi$ \\
\hline+ & 24 & 14 & & 0.026 & 0.308 \\
- & 4 & 10 & & \\
\hline
\end{tabular}

TLR4, Toll-like receptor 4 .

It has previously been suggested that TLR4 is one of the key factors in tumor growth regulation, independent of its immune activity, in breast cancer and that the oncogene is closely associated with the outcome of TP53 wild-type breast cancer (36). Another study in breast cancer indicated that TLR4 activation by lipopolysaccharide (LPS) triggers the Akt/glycogen synthase kinase-3 $\beta / \beta$-catenin signaling pathway, leading to breast cancer migration and metastasis (37). In colorectal cancer, TLR4 expression, as determined by IHC staining, is strongly associated with survival and recurrence assessed by survival analysis and prediction (38). In addition, the demethylation of TLR4 by Sp1 promotes activation of the $\mathrm{NF}-\kappa \mathrm{B}$ pathway in gastric cancer (39). Taken together, TLR4 may serve a key role in carcinogenesis.

The present study used IHC to confirm that TLR4/MyD88 expression was upregulated in NSCLC tissues compared with in benign lung tissues. The results indicated that TLR4 may be a biomarker for NSCLC diagnosis. Due to the small sample size, no association was detected between TLR4 and clinical characteristics. In addition, the TLR4-positive rate was similar in N1-2 tissues compared with in N0 tissues, with no significant difference; more cases should be assessed in future to test for a difference. Nevertheless, lower TLR4/MyD88 expression levels were markedly associated with a longer survival rate in patients with NSCLC, as determined using Kaplan-Meier database analysis. Survival prediction in oral squamous cell carcinoma previously demonstrated that high TLR4 and MyD88 expression likely results in the production of proinflammatory cytokines, chemokines and growth factors; suppression of TLR4 could enhance anticancer immunity and lead to a good prognosis (40).

EMT has been reported to be very important in metastasis and is closely linked to E-cadherin. Previous studies have reported that the TLR4/MyD88 and EGFR signaling pathways are associated with cancer metastasis (41-43), and several lines of evidence have indicated that TLR4 and EGFR promote metastasis of several types of cancer by affecting the 
A

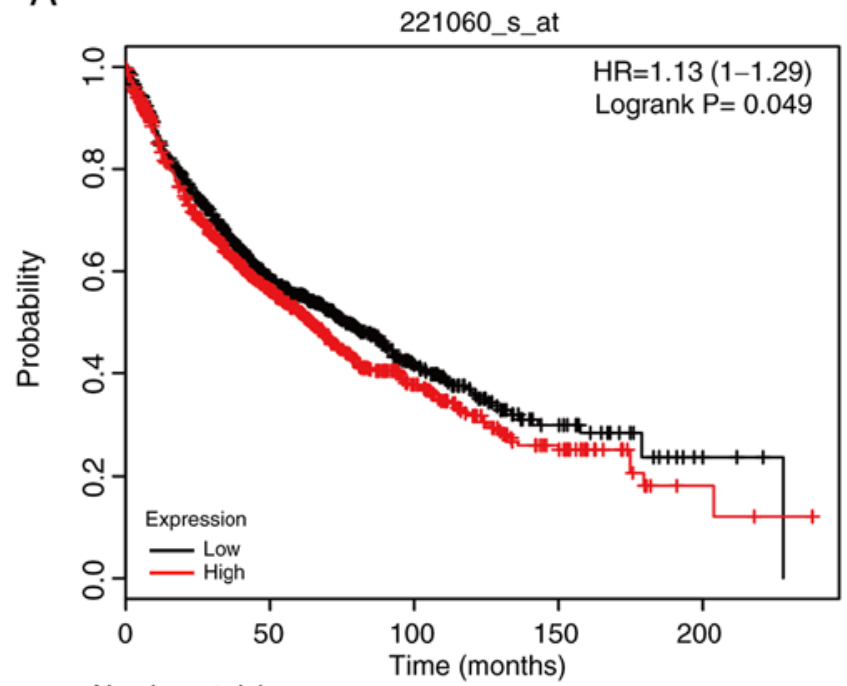

Number at risk

$\begin{array}{lllcll}\text { Low } & 967 & 436 & 97 & 26 & 4 \\ \text { High } & 959 & 392 & 106 & 31 & 3\end{array}$

C

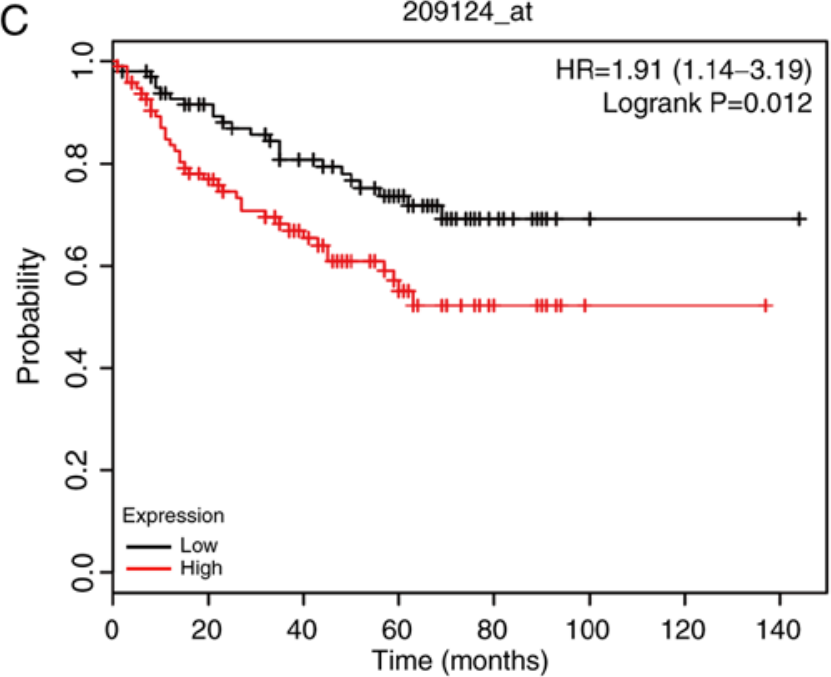

Number at risk

$\begin{array}{llllclll}\text { Low } 98 & 79 & 62 & 43 & 12 & 2 & 1 & 1 \\ \text { High } 97 & 66 & 47 & 28 & 8 & 1 & 1 & 0\end{array}$

B

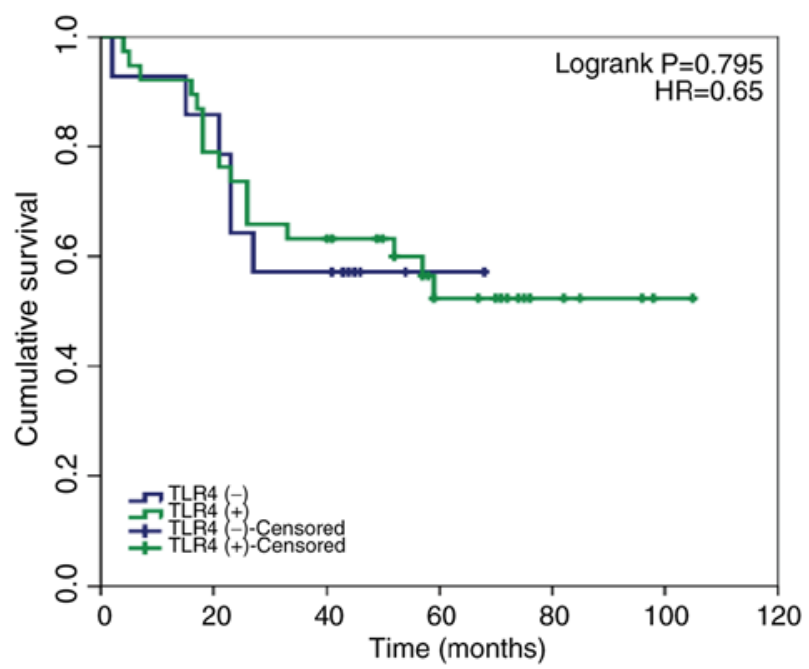

D

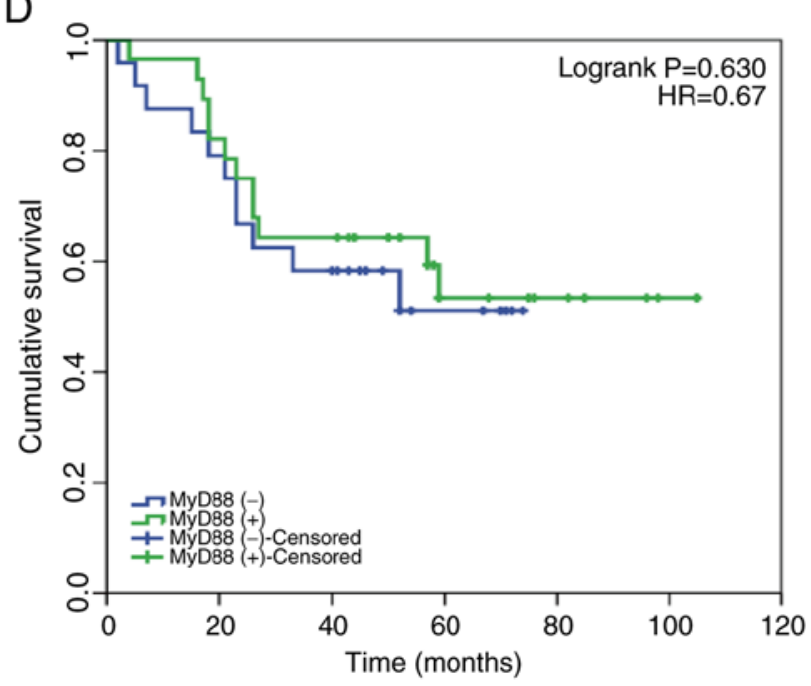

Figure 6. TLR4 and MyD88 expression as clinical outcome prognosticators for patients with lung cancer. Survival analysis of (A) TLR4 and (C) MyD88 expression in patients with lung cancer using the Kaplan-Meier Plotter database. Kaplan-Meier curve survival analysis of patients with lung cancer stratified according to the expression levels of (B) TLR4 and (D) MyD88. HR, hazard ratio; TLR4, Toll-like receptor 4.

EMT process (44-46). Furthermore, a previous study revealed that curcumin liposome exerts antitumor effects by affecting proliferation- and apoptosis-related molecules in rabbits (47). In addition, curcumin inhibits lung cancer growth through the regulation of vascular endothelial growth factor signaling in mice (48). This study demonstrated that curcumin could, to a large extent, block migration, upregulate the expression of E-cadherin and suppress the expression levels of vimentin. Furthermore, the expression of transcription factors associated with E-cadherin was markedly decreased. Combining these data and the previous results, it was hypothesized that curcumin could inhibit EMT via downregulating the TLR4 and EGFR signaling pathways, and increasing E-cadherin expression, in order to control NSCLC cell migration.
A previous study confirmed that curcumin can directly bind to MD-2, which is the upstream regulator of TLR4, similar to LPS, and form a curcumin-MD-2/TLR4 complex (49). In vivo, the curcumin analog $\mathrm{L} 48 \mathrm{H} 37$ improves survival and protects lungs against LPS-induced injury in septic mice via its interaction with MD-2 (50). In this study, a series of functional experiments were performed and the results demonstrated an anti-proliferative effect in NSCLC cells treated with curcumin. Subsequently, the anti-proliferative mechanism of curcumin was investigated. Curcumin induced $\mathrm{G}_{2} / \mathrm{M}$ phase arrest by controlling certain checkpoints of the cell cycle, including cyclin A1, cyclin A2, cyclin B1, cyclin D1, cyclin E1, CDK1, $\mathrm{p} 15$ and $\mathrm{p} 21$. Activation of the AP-1 protein upregulates cell cycle promoters, such as cyclins and CDKs, and suppresses 
cell cycle inhibitors such as CDKIs (51). The present results demonstrated that the expression levels of AP-1 were markedly decreased following curcumin treatment, which explains the decrease in cyclin A1, cyclin A2, cyclin B1, cyclin D1, cyclin $\mathrm{E} 1$ and $\mathrm{CDK} 1$, and the increase in 15 and $\mathrm{p} 21$; these results indicated that curcumin may serve a key role in modulating the cell cycle transition in NSCLC via altering the levels of JUN family proteins, thereby further affecting cell cycle regulators, particularly cyclins, CDKs and CDKIs.

The present study demonstrated that curcumin significantly inhibited the expression of TLR4/MyD88 and EGFR in a doseand time-dependent manner. Furthermore, the inhibitory action could be reversed by EGF in curcumin-treated NSCLC cells. The results of a Transwell migration assay provided evidence of the anti-migratory effect of curcumin, and curcumin was revealed to affect the expression of metastasis-related proteins. In addition, an analysis was performed to determine the association between lymph node metastasis and TLR4/MyD88 expression; however, no statistical significance was determined. The possible reason for this discrepancy may be the small sample size. Previous studies have reported that TLR4/MyD88 cooperates with EGFR and takes part in cancer metastases $(52,53)$. Therefore, it was hypothesized that curcumin may affect cell proliferation and migration in NSCLC through a synergistic effect on the TLR4/MyD88 and EGFR pathways. However, there was a limitation to the study. The bioavailability of curcumin was very low, which limited the progress of animal experiments; further studies aim to conduct in vivo experiments once the bioavailability problem has been resolved.

In conclusion, this study reported that TLR4/MyD88 expression was significantly upregulated in NSCLC. Curcumin treatment significantly reduced the proliferation and migration of NSCLC cells, possibly through TLR4/MyD88-EGFR-mediated inhibition of AP-1 protein and suppression of the EMT process. In the present study, preliminary evidence of curcumin-induced synergistic regulation of the TLR4/MyD88 and EGFR signaling pathways was obtained; however, there remains a lack of direct evidence; therefore, further studies are required.

\section{Acknowledgements}

Not applicable.

\section{Funding}

This study was supported by the China Postdoctoral Science Foundation (grant no. 2017M613008), the National Natural Science Foundation of China (grant nos. U1502222, 81702295 and 81602029), and the Yunnan Province Applied Foundation Project (grant no. 2018FB138).

\section{Availability of data and materials}

All data generated or analyzed during this study are included in this published article.

\section{Authors' contributions}

LZ, XT, QF, CG, RL, ZL, YZ, HT, QL, ML, HH, BZ, ZL and $\mathrm{CL}$ performed the research. XS and RL designed the study;
LZ, RL, XT and QF performed the statistical analysis; QF, LZ, XT and XS wrote the study. All authors have read and approved the final manuscript.

\section{Ethics approval and consent to participate}

This study was approved by the Ethics Committees of The Third Affiliated Hospital of Kunming Medical University, and informed consent was obtained from the patients.

\section{Patient consent for publication}

Not applicable.

\section{Competing interests}

The authors declare no that they have no competing interests.

\section{References}

1. Chen W, Zheng R, Baade PD, Zhang S, Zeng H, Bray F, Jemal A, Yu XQ and He J: Cancer statistics in China, 2015. CA Cancer J Clin 66: 115-132, 2016.

2. Siegel RL, Miller KD and Jemal A: Cancer statistics, 2017. CA Cancer J Clin 67: 7-30, 2017.

3. Torre LA, Bray F, Siegel RL, Ferlay J, Lortet-Tieulent J and Jemal A: Global cancer statistics, 2012. CA Cancer J Clin 65: 87-108, 2015

4. Torre LA, Siegel RL and Jemal A: Lung cancer statistics. Adv Exp Med Biol 893: 1-19, 2016.

5. Kiuchi F, Goto Y, Sugimoto N, Akao N, Kondo K and Tsuda Y: Nematocidal activity of turmeric: Synergistic action of curcuminoids. Chem Pharm Bull (Tokyo) 41: 1640-1643, 1993.

6. Shishodia S, Sethi G and Aggarwal BB: Curcumin: Getting back to the roots. Ann NY Acad Sci 1056: 206-217, 2005.

7. Shishodia S: Molecular mechanisms of curcumin action: Gene expression. Biofactors 39: 37-55, 2013.

8. Aggarwal BB and Sung B: Pharmacological basis for the role of curcumin in chronic diseases: An age-old spice with modern targets. Trends Pharmacol Sci 30: 85-94, 2009.

9. Aggarwal BB and Harikumar KB: Potential therapeutic effects of curcumin, the anti-inflammatory agent, against neurodegenerative, cardiovascular, pulmonary, metabolic, autoimmune and neoplastic diseases. Int J Biochem Cell Biol 41: 40-59, 2009.

10. Kuttan R, Bhanumathy P, Nirmala K and George MC: Potential anticancer activity of turmeric (Curcuma longa). Cancer Lett 29: 197-202, 1985.

11. Kuttan R, Sudheeran PC and Josph CD: Turmeric and curcumin as topical agents in cancer therapy. Tumori 73: 29-31, 1987.

12. Mishra A, Liu S, Sams GH, Curphey DP, Santhanam R, Rush LJ, Schaefer D, Falkenberg LG, Sullivan L, Jaroncyk L, et al: Aberrant overexpression of IL-15 initiates large granular lymphocyte leukemia through chromosomal instability and DNA hypermethylation. Cancer Cell 22: 645-655, 2012.

13. Demaria S, Pikarsky E, Karin M, Coussens LM, Chen YC, El-Omar EM, Trinchieri G, Dubinett SM, Mao JT, Szabo E, et al: Cancer and inflammation: Promise for biologic therapy. J Immunother 33: 335-351, 2010.

14. Katoh H, Wang D, Daikoku T, Sun H, Dey SK and Dubois RN: CXCR2-expressing myeloid-derived suppressor cells are essential to promote colitis-associated tumorigenesis. Cancer Cell 24: 631-644, 2013.

15. Wang L, Zhang H, Rodriguez S, Cao L, Parish J, Mumaw C, Zollman A, Kamoka MM, Mu J, Chen DZ, et al: Notch-dependent repression of miR-155 in the bone marrow niche regulates hematopoiesis in an NF- $\kappa \mathrm{B}$-dependent manner. Cell Stem Cell 15: 51-65, 2014.

16. Garza-Gonzalez E, Bosques-Padilla FJ, Mendoza-Ibarra SI, Flores-Gutierrez JP, Maldonado-Garza HJ and Perez-Perez GI: Assessment of the toll-like receptor 4 Asp299Gly, Thr399Ile and interleukin-8-251 polymorphisms in the risk for the development of distal gastric cancer. BMC Cancer 7: 70, 2007. 
17. He W, Liu Q, Wang L, Chen W, Li N and Cao X: TLR4 signaling promotes immune escape of human lung cancer cells by inducing immunosuppressive cytokines and apoptosis resistance. Mol Immunol 44: 2850-2859, 2007.

18. Cheng I, Plummer SJ, Casey G and Witte JS: Toll-like receptor 4 genetic variation and advanced prostate cancer risk. Cancer Epidemiol Biomarkers Prev 16: 352-355, 2007.

19. Chicoine MR, Zahner M, Won EK, Kalra RR, Kitamura T, Perry A and Higashikubo R: The in vivo antitumoral effects of lipopolysaccharide against glioblastoma multiforme are mediated in part by Toll-like receptor 4. Neurosurgery 60: 372-381, 2007.

20. Semlali A, Reddy Parine N, Arafah M, Mansour L, Azzi A, Al Shahrani O, Al Amri A, Shaik JP, Aljebreen AM, Alharbi O, et al: Expression and polymorphism of toll-like receptor 4 and effect on NF- $\kappa \mathrm{B}$ mediated inflammation in colon cancer patients. PLoS One 11: e0146333, 2016.

21. Köe M: GPCRs and EGFR-Cross-talk of membrane receptors in cancer. Bioorg Med Chem Lett 27: 3611-3620, 2017.

22. Lev-Ari S, Starr A, Vexler A, Karaush V, Loew V, Greif J, Fenig E, Aderka D and Ben-Yosef R: Inhibition of pancreatic and lung adenocarcinoma cell survival by curcumin is associated with increased apoptosis, down-regulation of COX-2 and EGFR and inhibition of Erk1/2 activity. Anticancer Res 26: 4423-4430, 2006.

23. De S, Zhou H, DeSantis D, Croniger CM, Li X and Stark GR Erlotinib protects against LPS-induced endotoxicity because TLR4 needs EGFR to signal. Proc Natl Acad Sci USA 112: 9680-9685, 2015.

24. Basu S, Pathak SK, Chatterjee G, Pathak S, Basu J and Kundu M: Helicobacter pylori protein HP0175 transactivates epidermal growth factor receptor through TLR4 in gastric epithelial cells J Biol Chem 283: 32369-32376, 2008.

25. Hsu D, Fukata M, Hernandez YG, Sotolongo JP, Goo T, Maki J, Hayes LA, Ungaro RC, Chen A, Breglio KJ, et al: Toll-like receptor 4 differentially regulates epidermal growth factor-related growth factors in response to intestinal mucosal injury. Lab Invest 90: 1295-1305, 2010.

26. Edge SB and Compton CC: The American Joint Committee on Cancer: The 7th edition of the AJCC cancer staging manual and the future of TNM. Ann Surg Oncol 17: 1471-1474, 2010.

27. Guo H, Luo H, Yuan H, Xia Y, Shu P, Huang X, Lu Y, Liu X, Keller ET, Sun D, et al: Litchi seed extracts diminish prostate cancer progression via induction of apoptosis and attenuation of EMT through Akt/GSK-3 $\beta$ signaling. Sci Rep 7: 41656, 2017.

28. Barnum KJ and O'Connell MJ: Cell cycle regulation by checkpoints. Methods Mol Biol 1170: 29-40, 2014

29. Karin M, Liu ZG and Zandi E: AP-1 function and regulation. Curr Opin Cell Biol 9: 240-246, 1997.

30. Schwabe RF, Bradham CA, Uehara T, Hatano E, Bennett BL, Schoonhoven R and Brenner DA: c-Jun-N-terminal kinase drives cyclin D1 expression and proliferation during liver regeneration. Hepatology 37: 824-832, 2003.

31. Toualbi-Abed K, Daniel F, Güller MC, Legrand A, Mauriz JL, Mauviel A and Bernuau D: Jun D cooperates with p65 to activate the proximal kappaB site of the cyclin D1 promoter: Role of PI3K/PDK-1. Carcinogenesis 29: 536-543, 2008.

32. Lv X, Wang H, Su A, Xu S and Chu Y: Herpes simplex virus type 2 infection triggers AP-1 transcription activity through TLR4 signaling in genital epithelial cells. Virol J 15: 173, 2018.

33. Gradisar H, Keber MM, Pristovsek P and Jerala R: MD-2 as the target of curcumin in the inhibition of response to LPS. J Leukoc Biol 82: 968-974, 2007.

34. Chattopadhyay S, Veleeparambil M, Poddar D, Abdulkhalek S, Bandyopadhyay SK, Fensterl V and Sen GC: EGFR kinase activity is required for TLR4 signaling and the septic shock response. EMBO Rep 16: 1535-1547, 2015.

35. Shehzad A, Lee J and Lee YS: Curcumin in various cancers Biofactors 39: 56-68, 2013.

36. Haricharan S and Brown P: TLR4 has a TP53-dependent dual role in regulating breast cancer cell growth. Proc Natl Acad Sci USA 112: E3216-E3225, 2015.

37. Li J, Yin J, Shen W, Gao R, Liu Y, Chen Y, Li X, Liu C, Xiang R and Luo N: TLR4 promotes breast cancer metastasis via Akt/GSK3//3-catenin pathway upon LPS stimulation. Anat Rec (Hoboken) 300: 1219-1229, 2017.
38. Sussman DA, Santaolalla R, Bejarano PA, Garcia-Buitrago MT, Perez MT, Abreu MT and Clarke J: In silico and ex vivo approaches identify a role for toll-like receptor 4 in colorectal cancer. J Exp Clin Cancer Res 33: 45, 2014.

39. Kim TW, Lee SJ, Oh BM, Lee H, Uhm TG, Min JK, Park YJ, Yoon SR, Kim BY, Kim JW, et al: Epigenetic modification of TLR4 promotes activation of NF- $\kappa B$ by regulating methyl-CpG-binding domain protein 2 and $\mathrm{Sp1}$ in gastric cancer. Oncotarget 7: 4195-4209, 2016

40. Sun Z, Luo Q, Ye D, Chen W and Chen F: Role of toll-like receptor 4 on the immune escape of human oral squamous cell carcinoma and resistance of cisplatin-induced apoptosis. Mol Cancer 11: 33, 2012.

41. Wang EL, Qian ZR, Nakasono M, Tanahashi T, Yoshimoto K, Bando Y, Kudo E, Shimada M and Sano T: High expression of Toll-like receptor 4/myeloid differentiation factor 88 signals correlates with poor prognosis in colorectal cancer. $\mathrm{Br}$ J Cancer 102: 908-915, 2010.

42. Wu K, Zhang H, Fu Y, Zhu Y, Kong L, Chen L, Zhao F, Yu L and Chen X: TLR4/MyD88 signaling determines the metastatic potential of breast cancer cells. Mol Med Rep 18: 3411-3420, 2018.

43. Miyamoto Y, Suyama K and Baba H: Recent advances in targeting the EGFR signaling pathway for the treatment of metastatic colorectal cancer. Int J Mol Sci 18: pii: E752, 2017.

44. Radisky DC: Epithelial-mesenchymal transition. J Cell Sci 118: 4325-4326, 2005.

45. He Z, Deng R, Huang X, Ni Y, Yang X, Wang Z and Hu Q: Lipopolysaccharide enhances OSCC migration by promoting epithelial-mesenchymal transition. J Oral Pathol Med 44: 685-692, 2015.

46. Ye K, Chen QW, Sun YF, Lin JA and Xu JH: Loss of BMI-1 dampens migration and EMT of colorectal cancer in inflammatory microenvironment through TLR4/MD-2/MyD88-mediated NF- $\kappa B$ signaling. J Cell Biochem 119: 1922-1930, 2018

47. Zhang X, Dai F, Chen J, Xie X, Xu H, Bai C, Qiao W and Shen W: Antitumor effect of curcumin liposome after transcatheter arterial embolization in VX2 rabbits. Cancer Biol Ther 20: 642-652, 2019.

48. Li X, Ma S, Yang P, Sun B, Zhang Y, Sun Y, Hao M, Mou R and Jia Y: Anticancer effects of curcumin on nude mice bearing lung cancer A549 cell subsets SP and NSP cells. Oncol Lett 16: 6756-6762, 2018

49. Wang Z, Chen G, Chen L, Liu X, Fu W, Zhang Y, Li C, Liang G and Cai Y: Insights into the binding mode of curcumin to MD-2: Studies from molecular docking, molecular dynamics simulations and experimental assessments. Mol Biosyst 11: 1933-1938, 2015.

50. Wang Y, Shan X, Dai Y, Jiang L, Chen G, Zhang Y, Wang Z, Dong L, Wu J, Guo G and Liang G: Curcumin analog L48H37 prevents lipopolysaccharide-induced TLR4 signaling pathway activation and sepsis via targeting MD2. J Pharmacol Exp Ther 353: 539-550, 2015.

51. Liu Y, Lu C, Shen Q, Munoz-Medellin D, Kim H and Brown PH: AP-1 blockade in breast cancer cells causes cell cycle arrest by suppressing G1 cyclin expression and reducing cyclin-dependent kinase activity. Oncogene 23: 8238-8246, 2004.

52. Gong WJ, Liu JY, Yin JY, Cui JJ, Xiao D, Zhuo W, Luo C, Liu RJ, Li X, Zhang W, et al: Resistin facilitates metastasis of lung adenocarcinoma through the TLR4/Src/EGFR/PI3K/NF- $\kappa \mathrm{B}$ pathway. Cancer Sci 109: 2391-2400, 2018.

53. Thuringer D, Hammann A, Benikhlef N, Fourmaux E, Bouchot A, Wettstein G, Solary E and Garrido C: Transactivation of the epidermal growth factor receptor by heat shock protein 90 via Toll-like receptor 4 contributes to the migration of glioblastoma cells. J Biol Chem 286: 3418-3428, 2011.

This work is licensed under a Creative Commons Attribution-NonCommercial-NoDerivatives 4.0 International (CC BY-NC-ND 4.0) License. 